УДК 004:9(81)

doi 10.17072/2219-3111-2020-4-106-116

\title{
CONNECTED BRAZIL AND DIGITAL HUMANITIES: THE PERSPECTIVE OF INTERPRETING MUSEUMS IN PORTO ALEGRE
}

\section{J. Bittencourt-Francisco}

Universidade Federal do Rio Grande do Sul, v. Paulo Gama, 110, Porto Alegre, Rio Grande do Sul, Brazil francisjulio@hotmail.com

A connected society implies a new concept of cultural patrimony which starts to exist when the space is changing from physical to the one of data flow. Cyberspace and new technologies in cultural institutions provide up-to-date information to their public that has the potential of acting as a co-author by creating and sharing. Accessing cultural information of the museum's collection online through the screen or electronic device is a global trend and leads individuals to interact, exchange knowledge and absorb social change. Can one think that it is the "Digital Age" that is imposing itself on teaching during the pandemic? Can you imagine that everyone will migrate to digital on equal terms, including the population most vulnerable to poverty? Are digital educational resources within easy reach of the entire student community? Do all families have sufficient digital literacy and financial conditions to assist and enable their children to access and use digital tools? The answers seem obvious. It is not possible to disregard or pretend to be a minor problem, which was known before the covid-19: the digital inequality. It has already been revealed that the place where you live defines insertion in the digital world. The outskirts of Porto Alegre, like many others in Brazil, are full of families with school-age children who face serious obstacles to accessing the world wide web. Difficulties ranging from not being able to buy a computer to being unable to pay the cost of equipment or connection services. That is why they are classified, in the surveys, as "second-class users", for making use of the internet based on more limited tools, such as cell phones, limited data access and access in public places. Digital inequalities connected with the pandemic. The article analyzes the connected Brazilian society and characterizes its involvement in the social media using the example of the museums of the city of Porto Alegre.

Keywords: Museums, Digital society, New technologies of Information, Connected Brazil, Porto Alegre.

\section{Introduction}

New technologies and media networks applied in practically all areas of knowledge, as well as the use of the Internet, have put concepts in crisis, as well as patterns of behavior and certainties, and also modified practices that demand new knowledge from scholars and professionals. Museums have changed significantly since these cultural institutions opened to new experiences, and by accompanying and hosting new technologies, they have gained new audience and added new categories, landscapes and social profiles that surround them.

The openings presuppose the possibility that individual and collective experiences of communication are carried out. The museums is too, but without losing sight of the intrinsic educational dimension of these institutions. Santos [2008] proposes that the museological practice builds knowledge, which is, therefore, educational. When museums showcase an experience such as an exhibition that could be aesthetic or a collection of art or specimens, people learn by holding on to emotion, for instance: when a museum creatively exposes its collections, showing through interesting and innovative interfaces, it increases its value to the public and fulfills its mission.

What is new is this article is a report on the participation of Brazilians in social media and the creation of what we call 'museological cartographies' in social media. This mapping details the participation of museums and cultural centers in social media and networks of a geographical area of the 1st Museal Region of the State of Rio Grande do Sul, which corresponds to the metropolitan area of Porto Alegre. This local experience represents, so we believe, a row model comparative to many examples of cities around the world. Social media is a net with no central point and regardless 
of physical space. We also provide information about Brazil, discuss new technologies in the cultural sphere, as well as in Brazilian society.

New challenges and dilemmas are imposed on museum professionals, educators and curators, as well as the general public, as digital communication expands. Due to a variety of communication alternatives available to everyone via the web, it is possible to share the benefits from a diversity of the audience, but this opportunity is usually ridden and uncovered. The job of the museum is to unveil a new sustainable format of marketing by the means of creativity and innovation, invest its results in museum exhibits, and then communicate it to the wider public.

This reality makes it possible to empirically identify strategies for the dissemination of collections and other information related to the institution that can be accessed by the public and updated by the institutions via the Internet. Moreover, the possibility of interaction is widened by the fact that digital platforms are ostensibly used by institutions, significantly altering the public experiences and creating a new dynamic in the museum that includes constant updating and monitoring the demands of either individuals or social groups.

\section{Online museum, museum-embedded technologies, and the crisis of concepts}

This type of decentralized mobility provided by the Internet and social media is so strong and fast that it proved capable of and indeed contributed to the seizure of political power in Brazil in 2018. The fact may go unnoticed, but it indicates the strength that communication and mobilization through social media present in a society like Brazilian, but also very similar to many others. Timing, sharing, and interchange are the keywords in this business of having common interests. Over the past seven or ten years, we have seen an exponential deployment of social media that becomes available to the public via the Internet, as well as the growth of technology applications for use on mobile devices. We are going to examine more carefully the influence of social media and new technologies in Brazil a, in particular on the museums of the city of Porto Alegre and its connections.

The phenomenon of the global use of social media is combined with the ability and willingness of people who, by participating, appear socially and tell others a bit about how they are. One should not circumvent, however, the great new mercantile power behind these media. The advertising and monitoring processes of individuals (who are users of social networks) use electronic tools that organize interests, direct their campaigns and online processes, reaping results at scale, but also sharing them with different interest groups. As for social media, especially Facebook, the authors [López and Ciuffoli, 2012] question whether the experience of participating in the app is really new or an old practice that dates back to Guttenberg's time. However, according to their analysis, "when one is touched by a magic wand of instantaneity and massification technologies, they only renew ancient rites and myths".

In the context of cultural institutions, the implications in relation to the forms of interaction, both between individuals and the interaction of individuals with objects, are directly linked to the fact that people begin to act in social contexts, conditioned by technological imperatives from the experiences of their past. According to Russ [at all, 2010], social media also represents changes in the way users interact using different communication models: one-to-one (i.e. from user to user), one-to-many (i.e. museum for users, such as blogs) and many-to-many (i.e. Wikis). Historically, one-to-one and one-to-many communication models have provided the framework for cultural authorities as established by museum programs. Regarding new technologies and museums, Rosali Henriques [2018] says that there are three types of virtual museums: e-booklet, virtual world museum and interactive online museums. According to her, the purpose of electronic brochures is only the presentation of the museum, functioning as a communication and marketing tool. The museum in the virtual world is the museum in which the institution presents more detailed information about its collection, with virtual visits to its assets. Finally, interactive online museums, which link cyberspace and the physical museum, add interactivity to attract visitors.

The collections shown in museum online exhibitions incorporate technology for digitizing collections that are safeguarded in technical reserves. The future looks bright, and among other novelties provided by available technologies, and those that develop rapidly, is that products become cheaper as time goes by, despite rapid obsolescence. Wired concepts of 'museum', 'object', 'place' and 'patrimony' are being reviewed in the light of 'informational revolution', and the official ICOFOM previous 
description of cultural heritage, authorship of artwork and digital society remains under discussion with pears to incorporate new concepts and rewrite the concept of the museum.

Let's examine this hypothesis. When material assets, patrimonial objects or artwork belonging to a museum are examined, it is assumed that each object is unique and requires long-term individual material attention, including an adequate storage environment. This is one of the reasons why so much importance is attached to the sustainability of institutions. From a technical point of view, according to Karp [2004], it is easy to duplicate the original digital object with complete precision. The difficulty in this case is that the technology used for reproduction will become obsolete after the digital record has been created and that the immaterial object of the original storage medium cannot be recovered later.

Further depreciation of the object of art or a specimen that is kept apart from the one in an exhibit in a digital file creates two objects. The second one carries all the resources of the Internet and the software on the net. However, they both perform two different peace of heritage good or asset. In this case, it is necessary to permanently be alert and, in the long run, to ensure that digital objects are transferred from one medium to another as technologies evolve.

Among the limitations this analysis calls for is the ability of museums to insert new professional profiles to their teams. In fact, the museum would need the resources of four collaborative profiles: "Digital Strategy Manager"; "Curator of Digital Collections"; "Promoter of Interactive Digital Experiences"; and "Online Community Manager". [Carvalho, Ana at all, 2018]

\section{Some use of Apply Technologies within museums}

Museums are bold enough to implement technologies such as QRCode $^{1}$, and profit from having labels on the exhibited items, improving the value of the museum and making content clearer and handier ${ }^{2}$. When adopting new technologies in exhibitions, museums create a kind of mixed mode by connecting to a computer network, allowing navigation through images, audio and online dialogues.

This is a greater integration that has connected the public with museums, archives, and libraries. This integration aims at establishing real time connection between researchers and institutions of memory and science. According to Solima, 2007 (p.6), the innovative use of the Internet in these institutions, especially in museums, allows us to experiment with 'push' approaches, i.e. it is intended to create a communication channel that is constantly open to users and visitors. Museums start to experiment with podcasting, i.e. creating a kind of digital media magazine, in which a user can participate and receive continuous feedback, or files in different formats that can be transferred to their portable device and used for asynchronously, at user-defined times and locations. Some museums provide podcast guides containing room by room description of the works featured in their exhibitions.

The concept of edutainment ${ }^{3}$ thus takes on added value: it is not only entertainment - often associated with innovative ways of using cultural content made available by technology - that can support the process of learning new knowledge, but its proposition is also valid in reverse. The visit, in fact, may represent an important opportunity for a museum to become more familiar with new digital devices, helping to reduce the cognitive resistance of those who are most reluctant to appropriate the new knowledge transmission potential offered by scientific progress [Solima, 2007, p.8].

Therefore, not only are museums changing places of interaction, always circumscribed to their physical limits, but also, and above all, modes of interaction that are increasingly open to activate twoway exchanges, capable of responding to the demands of emerging social relations. Some online museums open spaces for participation (discussion board) on emerging issues and make them accessible to the public: site visitors are invited to express their opinion and compare it with other users. The blogs of museums and cultural centers are just one of many examples of experiments with this form of information exchange that has begun in recent years. In our research, to be seen ahead, we concluded that there is a direct connection between the local public and their district museums run by the municipality.

Other examples of technology within museums today are where artists incorporate the scent into the aesthetic experience by "hovering" around the museum exhibit galleries with the smell of gunpowder, grass, jasmine, pine, and patchouli. Other social networks such as Instagran, 500px, Flickr, Pinterest, Photobucket, PictureSocial, and Bluecanvas are experts in art and photography that can be posted by the authors and shared with the public or websites that the artists themselves participate in to publicize their work. ${ }^{4}$ 


\section{Geographical, economic, cultural, and social Brazil}

With around 5.500 cities and over $3.000^{5}$ museums spread through the country, Brazil has approximately 5,000 kilometers from the southern tip to the far north, and from east to west, on the northeast-northwest axis. Such a big territory comprises five different regions that are culturally and environmentally diverse, as well as showing different history and expectations as societies. The north of the country is the widest area and is still mostly covered by rain forest, although it hosts 3 major cities: Manaus, Belem, and Porto Velho. By the northern region, weather is humid and hot, the population spreads with low density over a vast territory which is not distinguished culturally ${ }^{6}$.

The northeastern region is mostly dry backlands where the climate is hot and rain is scarce. It is the oldest region of the country colonized by the Portuguese who brought in blacks and captured Amerindians to work as slaves, growing and harvesting sugarcane. In the dry flat backland called 'caatinga', cattle farming was adopted by colonial rulers who directed their occupation with the strategical role of opening pathways to the north and west, when shipping along the coastline was very difficult for six months of the year due to against monsoons winds. In the 'caatinga' backlands ecosystem, the temperature is high and the climate is harsh with a drought that remains for decades, but, on the contrary, it is where the Brazilian culture is richer and has more roots, syncretism and diversity. The countryside is mostly semi-desert inhospitable areas. Historically, the dry backlands were ruled by landlords called 'coronéis' occupying huge piece of land, called 'sesmarias', representing 'latifúndios' of thousands of acres. This part of the country is the poorest, despite the excellent educational structure in some cities such as Salvador, Recife and Fortaleza.

The country has reduced its territory in the temperate climate zone which geographically points to the south. The southeastern and southern regions, the European migratory mark is visible. Over there, industry, services and educational level of the population stand out. The southeastern region has a greater concentration of black Brazilians due to the influence of the $19^{\text {th }}$ century coffee plantation economic circle, the last economic cycle before the industrialization of the region, which became the most advanced in the country, especially São Paulo and Rio de Janeiro.

The south of the country lies in the temperate zone and received many immigrants, especially Portuguese, Germans and Italians, as well as Poles, Russians and Spaniards. The state also represents the Brazilian 'alamo' where the 'gaúchos ${ }^{7}$ ' have a history of fighting with their neighbors to defend and define their final borders with Uruguay and Argentina, meaning a long tradition of armed disputes with the two countries. The South Brazil comprises three states: Rio Grande do Sul, the southernmost bordering Argentina and Uruguay, with its capital Porto Alegre, Santa Catarina with Florianópolis as capital and Paraná where Curitiba is the political center.

The fifth region of the country is the Brazilian Midwest that occupied the very center of South America. It has sparse population density and a transition point between two ecosystems: here Amazonia and the Pantanal (wetlands) take place, but both are losing space nowadays to monocultures such as soybeans, sugarcane, and cotton but also to prairies to raise cattle. This ecosystem suffers from wildfires, same of then criminal, during the dry season with the aim to increase cattle space. The agrobusiness has gained momentum in the Brazilian Midwest in the last 20 years as the region became the world largest exporter of animal protein, soybean, and cotton, but unfortunately these huge monoculture plantations or farms developments has been growing in exchange of environmental devastation. One other sad characteristic of the region is the lack of transport infrastructure to drain production to the ports of the coastline which increases final product price.

The characteristics mentioned so far, which were geographical, economic, cultural, and social, appears in today's behavior of the most part of the Brazilian people in terms of the use of communication technology, which is of great interest to museums and their administrators. Participation in social networks through the Internet, as well as the interest for new technologies such as handsets and mobile phone applications are important in the country. This new way of connecting with technology is adopted by many museums to approach their public or to keep up with new forms of communication.

It is worth mentioning the political organization of the country according to the 1988 Constitution. Brazil has three levels of public administration. The first one is the municipality level, referring to the city, county, or district governed by a mayor and his secretaries. The second is the state, or province, ruled by the governor and his departments' chiefs. Each state has a capital, normally the biggest and most important city. The last level is the federal or the union level, which comprises the center of 
the power. The Republic of the Brazilian Federated States has its home in the Federal District, a neutral city, as we all know, named Brasília which is in the very center of the country, where the President and his executive ministers have their offices.

The country is formed by twenty-six Federated States (and the Federal District) with about 210 million inhabitants. Members of parliament, as well as members of the executive branch of three levels, are elected by the people, as the country has 147 million voters ${ }^{8}$. Each of the mentioned public entities, municipality, state and union, has its own culture departments and, consequentially, autonomy and independency. This means three different cultural policies and budgets, to which their museums are linked.

Brazil is the $5^{\text {th }}$ largest land surface on the globe marked by national borders, and its unifying language is the Portuguese, the only country in the Americas where it is spoken. One interesting feature is the diversity of its inhabitants, composed of social groups of different origins and with high rates of miscegenation among themselves. In Brazil, in general, regional inequalities draw attention, both in terms of population and level of formal education, but also in urbanism and infrastructure.

The country's natural resources, internal market, agriculture, and industry have global power, but persistent problems that may be linked to the nation's historical process of economic viability, give a social stain colored by violence, corruption, a crisis of values, and lack of political stability. Such blemishes reflect the weak, or at least not steady, late economic growth. The high unemployment rate and low educational level of the population, as well as the marked differences ${ }^{9}$ between Brazilians, would not be deserved only by the already mentioned positive attributes. It is interesting to note that the Brazilian territory is inserted in a sort of 'spearhead' of the western world, like the American continent, the last territories to be colonized by Europeans in the traditional mold of the early modern age, when the colonizers brought their mercantile and religious frameworks of the time.

Further, it is no surprise that in this scenario, Brazilian online communities have quietly tran sformed local society. It has become a force capable of blending millions of followers who are influenced and able to make choices, supporting and replicating political ideas of 'leaders' whose social networking platforms are echoed through written messages, audio and video, surprising and overcoming political forces that do not mobilize or use such a direct form of communication. It has recently been shown that many of these digital influencers are really right-wing foreign-born that have been translated into Brazilian reality, bringing the capability to use electronic algorithmics to direct misinformation firing fake news among millions of people to score followers and elect local politicians.

Habermas explains this by the fact that this is not the relationship of a single individual to something in the objective world that can be represented and manipulated, but the intersubjective relationship that the subjects who speak act assume trying to understand something among themselves .

In doing so, communicative actors move through natural language, drawing on culturally transmitted interpretations, and refer to something simultaneously in an objective world, their ordinary social world, and their own subjective world [Habermas 1984, p. 392].

\section{Connected Brazil and how Brazilians use new communication technologies}

To comprehend it more deeply, we use the McKinsey Brazil Digital Institute Report ${ }^{10}, 2019$ [p.35] on the participation of Brazilians in social networks ${ }^{11}$. Following the source, 83 million people use the Internet daily, (two out of every three Brazilians). This puts the country above average in terms of the Internet access devices among those who use it. Also, in terms of the number of hours per day (online), the index is one of the highest. According to Google ${ }^{12}$, in 2018 Brazilians spent an average of 9 hours a day connected, almost half via mobile devices, and about 3.5 hours a day posting on social media, up $12 \%$ over the last 4 years. It is important to point out that $95 \%$ of the active population has smartphones. However, according to the same source, in Brazil, there are 20 million mobile app users of as Uber and 7 million Netflix subscribers .

According to the study of McKinsey Institute, the country was ranked 2nd or 3rd among the most interactive social media platforms, including Facebook ${ }^{13}$, Instagram ${ }^{14}$, YouTube ${ }^{15}$, WhatsApp ${ }^{16}$ and Linked $n^{17}$. The survey shows that $95 \%$ of the population has a TV set, $89 \%$ possess a mobile phone of any type ( $71 \%$ have a smartphone), $38 \%$ have a laptop or desktop computer, and $15 \%$ possess tablets. It has been accounted that $83 \%$ participate in online chat, $56 \%$ use social media, $54 \%$ watch news and use search engines on the Internet, and 41 million emails are sent daily. 
Yet, there is plenty of room for digital inclusion in the life of the population, and the growth potential of digital and technological industries is shown to be major business opportunities, especially in e-commerce and distance learning (e-learning), which is growing and consolidating in the country ${ }^{18}$, despite the quality problems of some courses and the lack of technological resources in others, as well as the low qualification of some 'monitors'. Online book reading is found only in $2 \%$ of the surveyed population. In addition, it should be noted that households with higher incomes have nearly four times more Internet penetration than households with lower incomes, which isolates and excludes those who really need it. Another reality worth mentioning is the average Internet speed in the country. Although it has risen five positions since 2014, ranking 133rd out of 200 countries, in 2018 at $2.58 \mathrm{mbps}$, it is still the lowest among many developed economies.

\section{The great Porto Alegre area and its museums: a study case.}

The city of Porto Alegre and its surrounding towns (The Great Porto Alegre area) is the capital of the Rio Grande do Sul State, the southernmost territory. It is here that the international migration is marked, especially Europeans who came as settlers in the late $19^{\text {th }}$ century, along with the 'gaucho, 19 style and way of life that are an important part of the local cultural heritage.

The study is based on the museums of the capital and surrounding municipalities within 100 kilometers axis from Porto Alegre. In this universe, we locate 87 institutions analyzes in the essay. To better systematize the work, we divide these institutions by ownership/management level, thus classifying institutions into federal (includes $80 \%$ of university museums that are under federal management), state, municipal and private museums, (called 'particular' - that includes $20 \%$ of the university museums which have private ownership) as illustrated in the following graphics.

Graph I

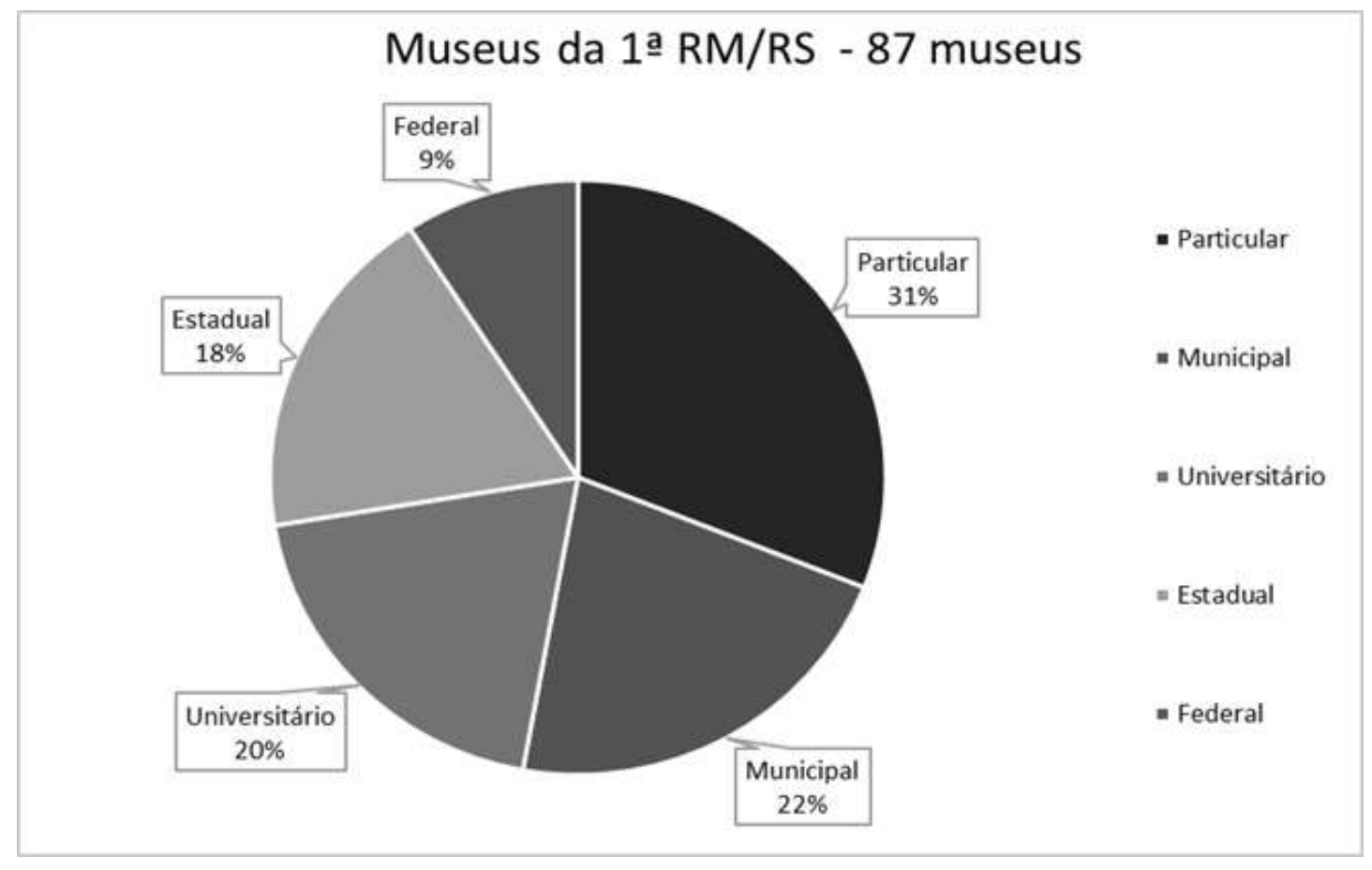

Most of the university museums are federally owned, and quite a few of the private ones are foundations or simply private museums. We can also distinguish them into thematic, historical, science and art museums ${ }^{20}$. Thus, Graph I show that state or public museums (federal, state, and municipal) account for $69 \%$ of all cultural institutions, while the remainder is represented by private ones.

Of the 87 museums (and cultural centers) surveyed that make up the majority of the 1st museum region, regardless of their type of ownership or management, we agreed, for a better understanding, on content aspects, for example: Charcoal Museum (in the city of Charqueadas) is thematic. The Julio de Castilhos' Museum is a historical museum (in the capital). The Iberê Camargo Foundation (in the capital) is an art museum and the Sciences and Technology Museum (in the capital) is a science museum. 


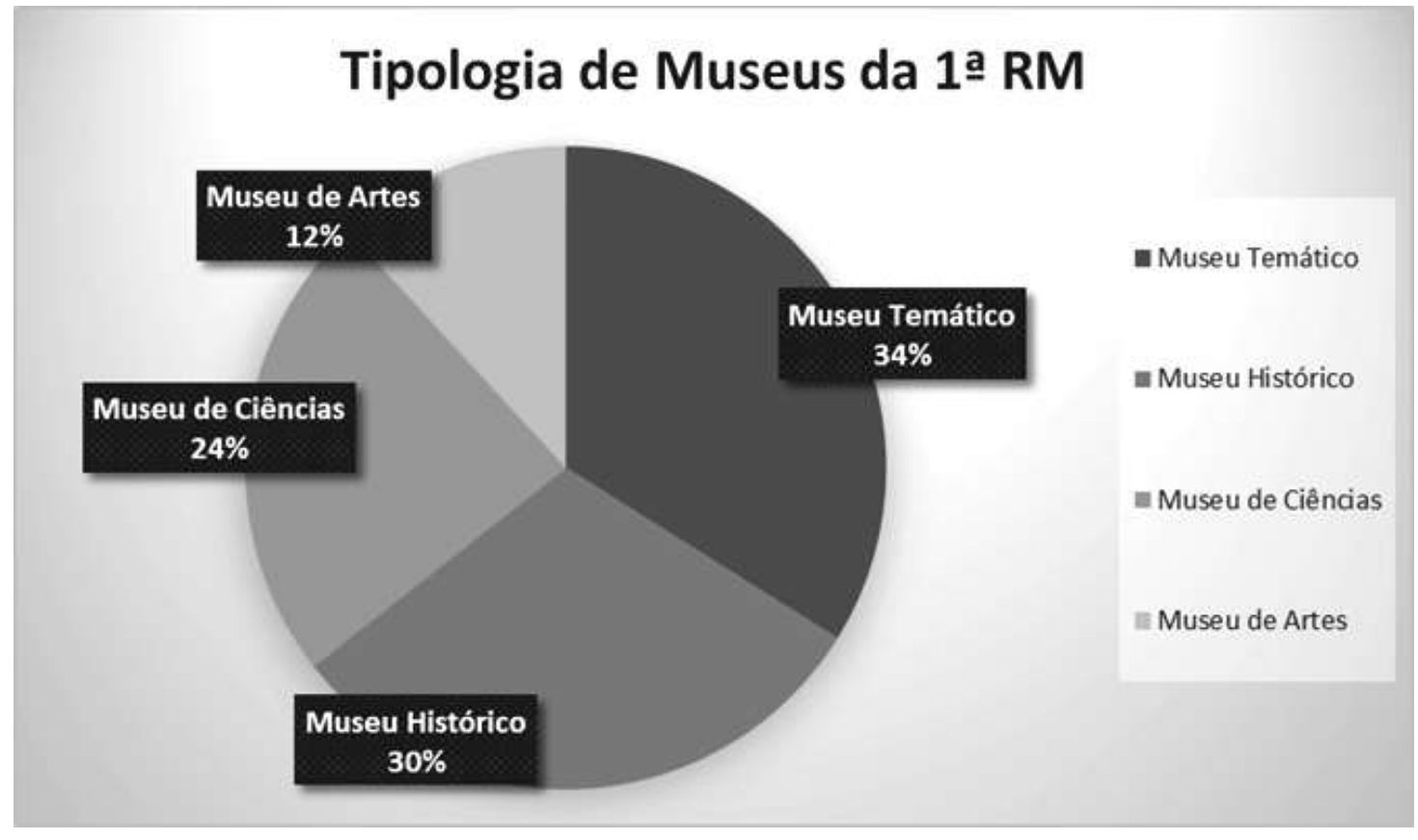

Our research aims to map out the museums in the Porto Alegre area $\left(1^{\text {st }}\right.$. Museal Region) that are present or represented in social media. According to our investigation, the Facebook platform stands out as the one of priority use. Our research is relevant for revealing the general position of the museums in the covered area, whether they have representation on the Internet in which platform or if they have their own web page, or if the Museum were closed during our research, as we observed in the chart below:

Graph III (Museums closed or with no page in the Internet)

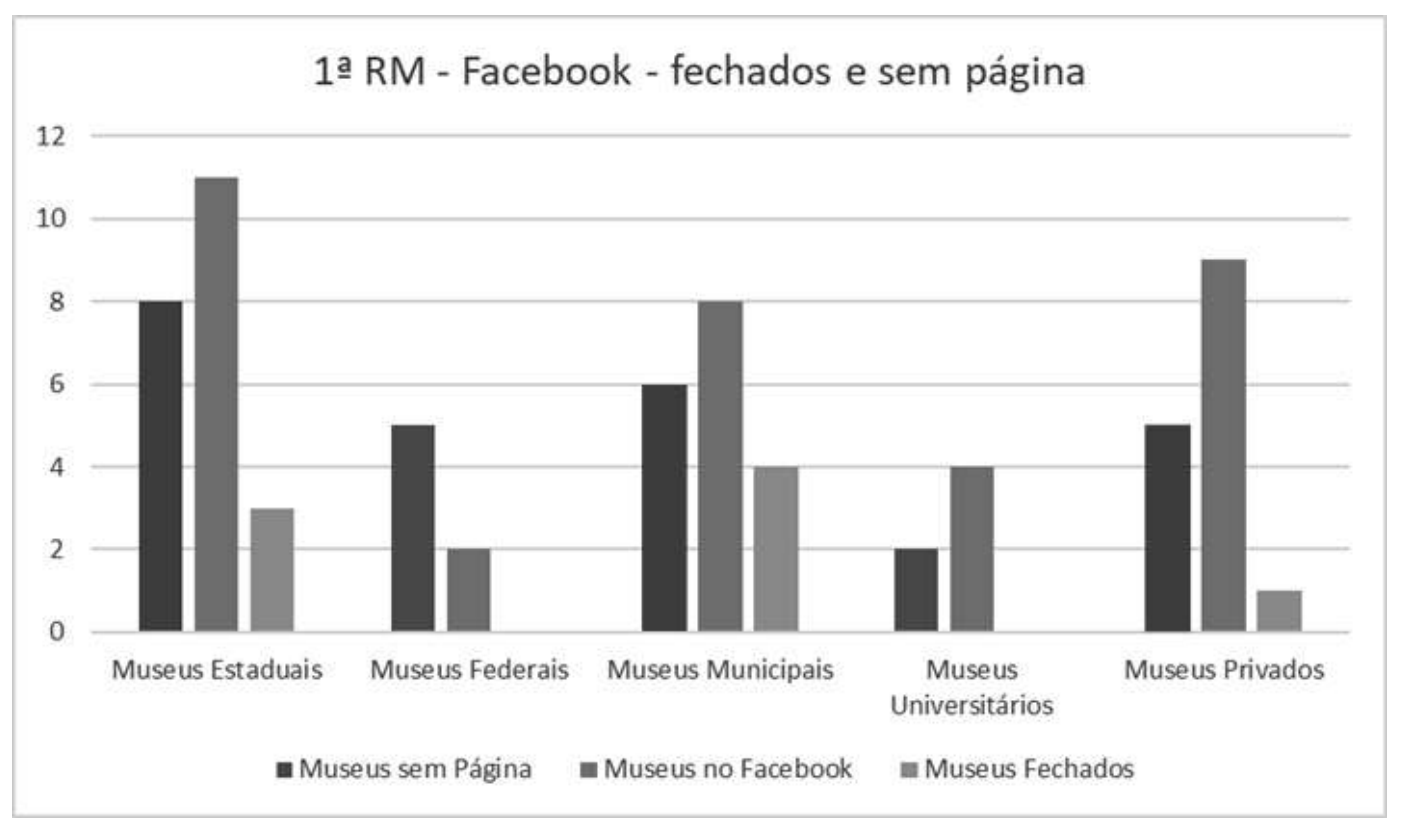


Graph IV (Museums - Presence in the Internet platforms - by management)

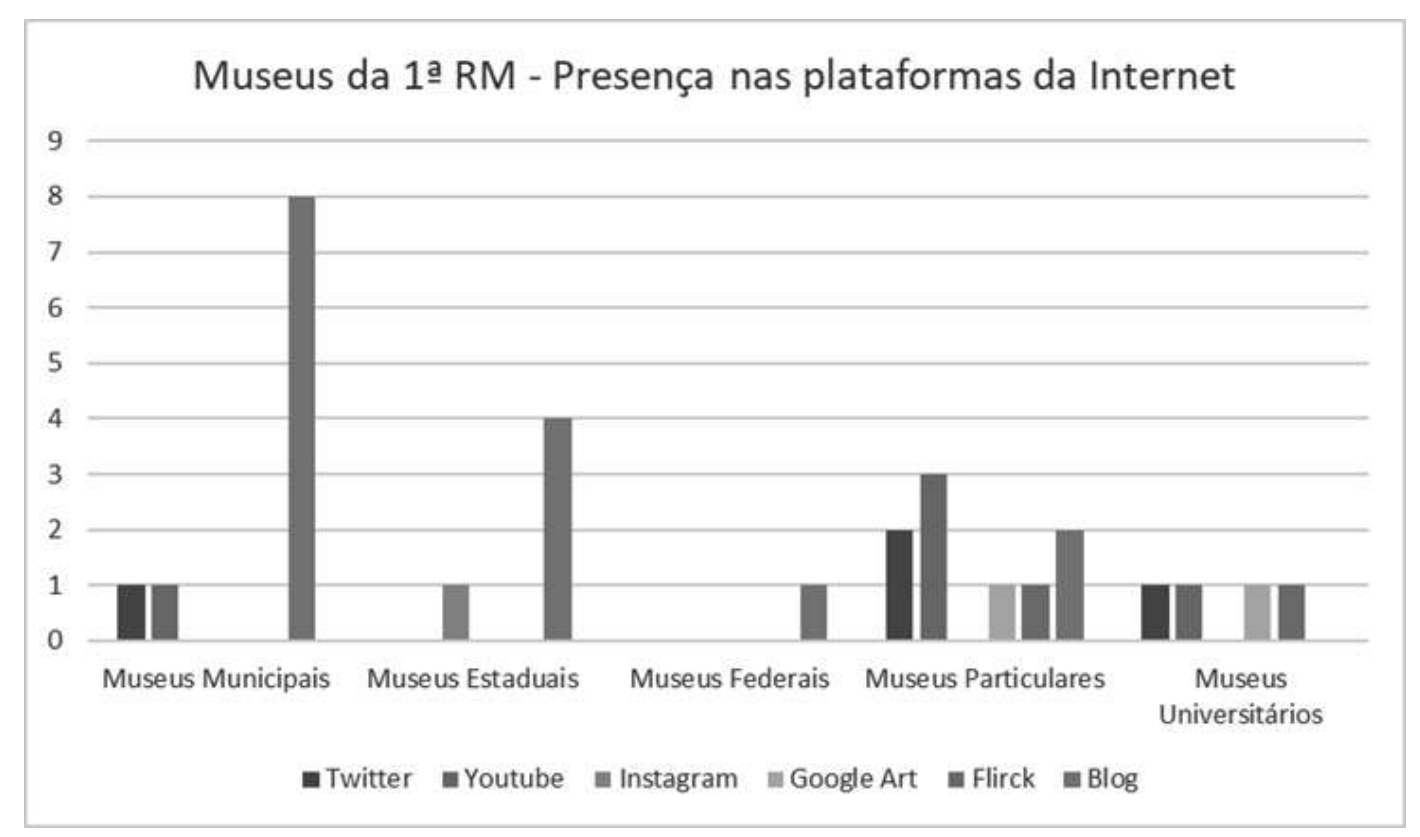

As for Graph III, it is easy to conclude that some museums are unable to sustain or finance their own homepage and alternatively create a Facebook page, obviously for budget reasons. We also found that many public museums (owned by municipal, state, or union) use their maintainer's web page (for example, the county, state, or the union culture department) with which they are linked, to grant them virtual space, for example, a link to their home pages.

Graph IV represents a broader view of the participation of museums (of the first museum region) on the Internet (excluding the Facebook platform shown earlier). We highlight the use of blogs by public museums (primarily municipal), as well as the variety of media in private and university museums. It is important to point out that blogs may confer important popular (public) participation to museums in ways of interaction and notice the possibility in the blog media for broader participation and opportunities of communication, which may include photos, movies, podcasts, interactivity, and text sharing. This may explain the greater proximity, as shown in our research, of the public to municipal museums, which may be more closely linked to their local content, which is community driven.

\section{Conclusion}

A technological perspective will support the museum in its development, stimulating the ability to present itself as an interlocutor, able not only to ask questions, but to provide adequate answers to many of the questions that visitors pose. We wonder if connecting means to innovate and how can digital potential be used to generate resources for museums and cultural institutions. How to apply resource mobilization practices to be used by social organizations? What innovative practices can unite the awareness of shared economies and digital channels that can support the financial sustainability of museums and cultural centers? These are questions to reflect the perspective of the use of technology in museums and cultural institutions. The use of some of the technological solutions described in the article, in fact, implies a certain familiarity of the user with the digital environment, as well as a propensity to use such tools, which cannot be referred to the issues considered in their entirety due to presence of significant differences related to gender, age or professional status. There is a potential number of users in Brazil who still do not adhere to the new demands that are focused on experimenting with technologies and socializing their knowledge. On the other hand, as already mentioned, the Brazilian population welcome and show interest in new technologies and connectivity.

The question arises: which kind of museum do we want? It will certainly always be presential and of quality, but we cannot abandon on modernity and technological changes that are coming in full force. Thus, we must ask whether museums are committed to fully participating in this field, taking the application of new technologies as a priority, in the sense that they can also support the 
remaining museological functions. The Internet implies potential in revitalizing political communication, but this potential is vulnerable according to the surrounding social and economic infrastructure. In the Porto Alegre area, as in a mirror applied to other cities in the world, it is possible to verify that the diversity of social media is present, but there is still plenty of room to grow. Democratizing information is one of the advantages of going online, and it certainly helps the museum's work in accomplishing its mission. These new tools show us that the need for memory and culture are important demands of the population, as they are represented at all levels of public administration, but also attract the interest of private groups. As we have seen in some cases, the use of social media and technologies enable museums to remain sustainable and, above all, to help cast information, integrate and exchange culture, which is essential in a country as large and different as Brazil.

\section{Notes}

${ }^{1}$ It is a $2 \mathrm{D}$ barcode that can be scanned by mobile devices. This code, after decoding, becomes a piece of text, a link that will redirect access to the content published on some site. Source:https://www.triscele.com.br/triscele/ interatividade/qr-code-em-exposicoes-museologicas, accessed 02.06.19.

${ }^{2}$ Some examples: https://www.handbuiltcreative.com.au/\#work, accessed 06.06.19.

${ }^{3}$ Edutainment, or edtech, meaning the merge between education and entertainment. Source:https://envolverde. cartacapital.com.br/edutainment-a-uniao-entre-educacao-e-entretenimento/, accessed 07.06.19.

${ }^{4}$ Source:: http://www.tecnoartenews.com/noticias/15-redes-sociais-para-artistas-compartilharem-seus-trabalhos/, accessed 07.06.19.

${ }_{6}^{5}$ Source: https://www.museus.gov.br/os-museus/museus-do-brasil/, accessed 09.06.19.

${ }^{6}$ Two great exception [among few small others] is the Emilio Goeldi Museum in Belem, Para State, and The Manaus Institute of Amazonian Research, at Manaus, Amazon State. Specially Belém, Manaus and surrounding areas have the infrastructure and direct connections with the rest of the country.

${ }^{7}$ Used as a gentile to name those born in the Brazilian state of Rio Grande do Sul. In addition, it is used to refer to a folklore type and a set of codified traditions spread by a cultural movement grouped together for this purpose. and known as Gaucho Traditions Center or CTG.

${ }^{8}$ In Brazil, voting is mandatory and the ballots are open to citizens from 16 to 70 years old. General elections take place every 4 years, and despite the high number of people participating in a single day [between 9:00 and 18:00], its results are usually determined in few hours, due to the use of electronic devices such as electronic ballot machine and biometrics. Source: http://www.tse.jus.br/imprensa/noticias-tse/2018/Agosto/brasil-tem-1473-milhoes-de-eleitores-aptos-a-votar-nas-eleicoes-2018, accessed 12.06.19.

${ }^{9}$ Source: https://portal.fgv.br/noticias/pobreza-e-desigualdade-aumentaram-ultimos-4-anos-brasil-revela-estudo, accessed 09.06.19.

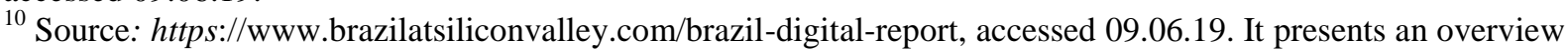
of the Brazilian economy, but also of innovation including the digital landscape. The data show that the country offers surprising opportunities and impressive numbers, but also many challenges in terms of innovation and productivity, its worst performers, but necessary to drive growth and social advancement.

${ }^{11}$ The methodology of the research on the participation of Brazilians in social networks was conducted in November 2018, and used a stratified sampling of 2,477 people living in urban areas, aged 15 to 60 , from economic classes A to D.

${ }^{12}$ CETIC.br; Consumer Barometer Google [2018]. Available at: https://www.consumerbarometer.com/en/, accessed 10.06.19.

${ }^{13} 130$ million users, the world's third-largest user base and pilot for new products such as event stories, game content, etc.

${ }^{14}$ Over 50 million users, second largest user base.

${ }^{15}$ Second in the world with about 69 million views per month.

${ }^{16}$ Over 120 million users, the most popular and used communication app in Brazil, with 91\% penetration among Internet users.

${ }^{17}$ With 29 million users, the 3rd largest base in the world.

${ }^{18}$ According to the Ministry of Education, between 2017 and 2018, the offer of distance learning graduation courses jumped from 6,583 to 15,394. The 133\% increase is a direct consequence of a Federal Bill of 2017 that loosensthe regulatory framework for this type of learning system in order to increase the offer of higher education courses in the country. In 2016, Brazil had 1.5 million students enrolled in distance learning, however, the scenario leads to a perspective that within five years there will be 2.27 million. Source: https://desafiosdaeducacao.com.br/polos-ead-em-crescimento/, accessed 21.07.19.

${ }^{19}$ The term is also given to people linked to livestock activity in regions of natural field occurrence, the pampa biome, which occurs in southern South America, in countries such as Argentina, Brazil and Uruguay, and those born in the Brazilian state of Rio Grande do Sul. The peculiar characteristics of its pastoral way of life would 
have forged a culture of its own, derived from the amalgam of Iberian and indigenous culture, adapted to the work performed on the properties called estancias. Sometimes the term is also considered similar or equivalent to other rural lifestyles in other cultures, such as the American cowboy, Chilean huaso and Mexican charro, for example.

${ }^{20}$ Not included here the museums of territory, anthropological and communitarian due to their reduced number. [at least one of each do exist in the studied geographical area: First Museological Region $-1^{\mathrm{a}} \mathrm{RM}$ ]

\title{
References
}

Carvalho, A. M., Pizarro A., Sarmento M. M. (2018), Competências para a transformação digital nos museus: o projecto Mu.Sa Museus e Estudos Interdisciplinares, in MIDAS - Museus e Estudos Interdisciplinares, № 9, available at: http://journals.openedition.org/midas/1463 (accessed 09.06.19).

Habermas, J. (1984), The theory of communicative action. Vol 1. Reason and the rationalizalion of society, Beacon Press, Boston, USA, 465 p.

Henriques, R. (2018), "Os museus virtuais: conceitos e configurações", Cadernos de Sociomuseologia, Vol. 56, № 12, pp. 53-70.

Karp, C. (2004), "El patrimonio digital de los museos en línea", Museum Internacional, UNESCO, № 221/222, pp, 44-51.

Lopéz, G. \& C. Ciuffoli (2012), Facebook es el mensaje: oralidad, escritura y después, Crujía ediciones, Buenos Aires, Argentina, $128 \mathrm{p}$.

Russ, A., Watkins, J, Kelly, L. \& S. Chan (2010), "Como as mídias sociais afetam a comunicação nos museus", Lumina Revista do Programa de Pós-Graduação em Comunicação da Universidade Federal de Juiz de Fora, Vol. 4, № 1, available at: www.ppgcomufjf.bem-vindo.net/lumin (accessed 09.06.19). Santos, M.C. (2008), "Encontros Museológicos - Reflexões sobre a Museologia, a Educação e o Museu", Coleção Museu, Memória e Cidadania, № 4, Rio de Janeiro.

Solima, L. (2007), "Nuove tecnologie della comunicazione", Economia dela Cultura, № 3, pp. 365-376.

Дата поступления рукописи в редакщиюю 12.12.2019

\section{СОЕДИНЕННАЯ БРАЗИЛИЯ \\ И ЦИФРОВЫЕ ГУМАНИТАРНЫЕ НАУКИ: ПЕРСПЕКТИВЫ ИНТЕРПРЕТАЦИИ МУЗЕЕВ В ПОРТУ АЛЛЕГРИ}

\author{
Д Битенкоурт-Франциско \\ Федеральный университет в Риу-Гранди-ду-Сул, \\ Паулу Гама, 110, Порту-Алегри, Риу-Гранди-ду-Сул, Бразилия \\ francisjulio@ hotmail.com
}

Использование новых технологий, Интернета и медиасетей практически во всех областях знаний оказало существенное влияние на музейную сферу, изменило понимание объекта наследия, породило явление «цифрового неравенства». Музеи значительно изменились с тех пор, как начали применять новые технологии: приобрели новые аудитории и социальный контекст.

В статье рассматривается проблематика использования бразильцами социальных сетей музеев, в частности, в таком аспекте, как «музеологическая картография». Подробно анализируется ситуация в бразильских музеях и культурных центрах в «модельном» для страны столичном регионе Порту-Аллегри.

Экспоненциальный рост и развертывание социальных сетей, медиа, которые стали общедоступными благодаря Интернету и мобильным устройствам, привел к появлению новых каналов коммуникации с аудиторией, расширил и укрепил связи между музеями и публикой. Музеи меняют не только места взаимодействия с аудиторией, прежде ограниченные их физическими пределами, но и способы взаимодействия, которые становятся все более открытыми для активизации двустороннего обмена, позволяющего гибко реагировать на запросы со стороны посе- 
тителей и сообществ. Некоторые онлайн музеи открывают дискуссионные площадки по возникающим вопросам и делают их открытыми для общественности: посетителей сайта приглашают высказать свое мнение и сравнить его с опытом других пользователей. Блоги музеев и культурных центров являются лишь одним из многих примеров экспериментов с этой формой обмена информацией. В ходе исследования сделан вывод о существовании прямой связи между местными сообществами и государственными музеями, находящимися в ведении муниципалитетов.

В Бразилии, с ее огромной территорией, существует около 5500 городов и поселений, в которых действует более 3000 музеев, расположенных по всей стране, во всех пяти регионах, различающихся в культурном и экологическом отношении, имеющих разную историю и ожидания общества. Согласно отчету Бразильского института цифровых технологий за 2019 г. об участии бразильцев в социальных сетях ежедневно Интернетом пользуются 83 млн человек (две трети бразильцев). По данным Google в 2018 г. бразильцы проводили в среднем 9 часов в день на связи (один из самых высоких индексов) и около 3,5 часов в день, размещая сообщения в социальных сетях.

Город Порту-Алегри является столицей штата Риу-Гранди-ду-Сул, самой южной территории страны. В данном проекте исследовались 87 музеев столицы и близлежащих муниципалитетов в пределах 100 км от Порту-Алегри. Они были разделены на группы по типу собственности / управления: федеральные (включая $80 \%$ университетских музеев, находящихся в федеральном управлении), государственные, муниципальные и частные; а также по видам коллекций (тематические, исторические, искусств, научные музеи). Учитывались только те музеи, которые имеют представительство на платформе Facebook.

Многие музеи Бразилии предпочитают создавать не сайты, а страницы в социальных сетях, что можно объяснить дефицитом бюджета на создание и поддержку сайтов. Социальные сети бесплатны для использования и публикации контента. Многие государственные музеи используют веб-страницу своего округа, штата или отдела культуры соответствующего профсоюза. Анализируется использование блогов государственными музеями (в первую очередь муниципальными) и разнообразие средств массовой информации в частных и университетских музеях.

Технологии способны поддержать развитие музея, сделать музей собеседником, дающим адекватные ответы на многие вопросы посетителей. Но развитие технологий ставит и проблемные вопросы: можно ли объединить средства для инноваций и использовать цифровой потенциал для создания ресурсов музеев и культурных учреждений? Как применить методы мобилизации ресурсов, которые будут использоваться общественными организациями? Какие инновационные практики могут объединить понимание общей экономики и цифровых каналов, которые будут поддержать финансовую устойчивость музеев и культурных центров? Эти вопросы отражают перспективу использования технологий в музеях и культурных учреждениях.

В районе Порту-Аллегри можно убедиться в том, как разнообразно используются различные социальные сети и какое множество возможностей для развития музеев открывается с их помощью. Демократизация информации - одно из преимуществ выхода в Интернет, и это, безусловно, помогает музею выполнять свою миссию. Активность бразильцев в социальных сетях и отклики, связанные с их вовлечением в музейную деятельность показывают нам, что важнейшей потребностью для населения является потребность в памяти и культуре. 